\title{
Analisis Trend Dan Grafik Barber Johnson Pada Efisiensi Tempat Tidur Di Rumah Sakit X Kota Bandung
}

\author{
Rd. Sekar Putri Defiyanti ${ }^{1}$, Sali Setiatin ${ }^{2}$, Aris Susanto ${ }^{3}$ \\ ${ }^{1,2}$ Program Studi D3Rekam Medis dan Informasi Kesehatan, Politeknik Piksi Ganesha Bandung \\ ${ }^{3}$ DPD PORMIKI Jawa Barat
}

\begin{tabular}{l}
\hline Article Info \\
\hline Article history: \\
Received June 28, 2021 \\
Revised July 15, 2021 \\
Accepted July 22, 2021 \\
\hline
\end{tabular}

Keywords:

Analysis

Trend

Barber Johnson

Bed

\begin{abstract}
Trend analysis is a statistical analysis method used for planning and evaluating efforts to minimize risk for the better. The purpose of this study was to analyze trends and barber johnson charts on the efficiency of bed use at X Hospital, Bandung City. This type of research is a qualitative method with a descriptive approach. Observations and interviews were carried out with data processing officers and medical record reporting officers, while secondary data was obtained from RL3 Year 2020 at Hospital X Bandung City. Data analysis using least square trend method and Barber Johnson chart. The results showed that the trend of BOR and BTO in Quarter I-IV of 2020 decreased. The trend of AvLOS and TOI in Quarter I and II increased, while in Quarter III and IV it decreased. Based on the results of the study, it can be analyzed that the use of beds at Hospital X Bandung City in 2020 has not been efficient, only reaching 20$60 \%$ while the standard value according to Barber Johnson is 75 $85 \%$, but it can be predicted that the TOI indicator will be more efficient, while the BOR indicator, AvLOS, and BTO are increasingly inefficient because their values are getting further away from the predetermined standard values. To increase efficiency in the use of beds, the hospital should evaluate the beds and improve the quality of service.
\end{abstract}

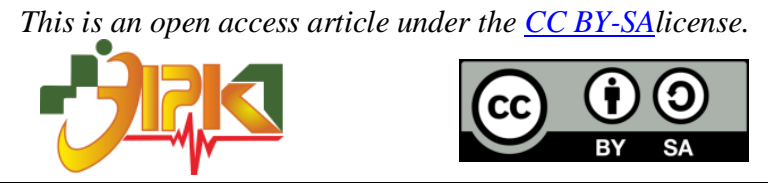

\section{Corresponding Author:}

Rd. Sekar Putri Defiyanti,

Program Studi D3 Rekam Medis dan Informasi Kesehatan,

Politeknik Piksi Ganesha Bandung,

Jl. Dalem tanubaya No.11 Desa Sindangpakuon Kecamatan Cimanggung, Sumedang - Jawa Barat.

Email: sekarputride29@gmail.com

\section{PENDAHULUAN}

Menurut [1] tentang Kesehatan menyatakan bahwa kesehatan adalah keadaan sehat baik secara fisik, mental, dan kesejahteraan bagi seseorang untuk hidup produkif secara sosial dan ekonomis. Rumah sakit sebagai salah satu Organisasi yang dapat memberikan pelayanan kesehatan terhadap masyarakat yang mempunyai fungsi utama untuk menyediakan dan menyelenggarakan upaya kesehatan yang bersifat menyembuhkan dan memulihkan.

Menurut [2] tentang Standar Pelayanan Minimal Rumah Sakit, rumah sakit adalah fasilitas pelayanan kesehatan yang mempunyai karakteristik yang sangat mendukung 
dalam upaya kesehatan. Sesuai dengan standar yang telah ditetapkan rumah sakit bertanggung jawab dalam pelaksanaan dan pengendalian untuk meningkatkan kesejahteraan pada kesehatan masyarakat, sehingga rumah sakit menyediakan pelayanan rawat inap, rawat jalan, dan gawat darurat baik meliputi pelayanan promotif, preventif, kurative, dan rehabilitatif. Salah satu upaya kuratif (penyembuhan penyakit) dan rehabilitatif (pemulihan kesehatan) rumah sakit menyediakan pelayanan rawat inap kepada pasien yang membutuhkan perawatan secara terus menerus untuk melakukan observasi, diagnosis, terapi atau rehabilitas dimana pasien menginap. Pelayanan rawat inap ini sangat berpengaruh terhadap tingkat efisiensi di rumah sakit.

Dalam menunjang tercapainya tertib administrasi sangat dibutuhkannya unit rekam medis dalam mengolah efisiensi pelayanan kesehatan di rumah sakit [3]. Menurut [4] tentang Rekam Medis, unit rekam medis berperan penting mengenai kegiatan pelayanan yang ada di rumah sakit, sebagai sumber informasi dalam bentuk dokumen yang berisikan catatan tentang identitas pasien dan segala bentuk kegiatan yang dilakukan atau diberikan kepada pasien.

Menurut [5] bahwa dalam upaya meningkatkan efektifitas rumah sakit, semua kegiatan di rumah sakit wajib dicatat dan dibuat laporan dalam bentuk Sistem Informasi Manajemen Rumah Sakit (SIMRS). Data yang dihasilkan tersebut dapat dipergunakan untuk mengolah data dan menyusun pelaporan rumah sakit berdasarkan [6] tentang Sistem Informasi Rumah Sakit. Pelaporan rekam medis terdiri dari 5 Rekapitulasi Laporan (RL) yaitu: RL 1 (Data Dasar Rumah Sakit), RL 2 (Data Ketenagaan), RL 3 (Data Kegiatan Pelayanan Rumah Sakit), RL 4 (Data Morbiditas/Mortalitas Pasien), RL 5 (Data Bulanan), proses pelaporan tersebut harus memiliki sistem pengolahan data yang baik sehingga dapat menyajikan data yang akurat mengenai tingkat efisiensi pada pelayanan rumah sakit.

Statistik rumah sakit yaitu statistik yang bersumber pada data rekam medik, sebagai informasi kesehatan yang digunakan untuk memperoleh kapasitas bagi praktisi kesehatan, manajemen dan tenaga medik dalam pengambilan keputusan [7]. Hubungan statistika dengan rekam medik sangatlah erat karena didalam menyediakan data atau informasi tentang kegiatan pelayanan di rumah sakit, data yang dihasilkan dari unit rekam medik dapat digunakan untuk menyusun laporan rumah sakit. Statistik rumah sakit juga bermanfaat sebagai bahan acuan dan sebagai bahan evaluasi untuk meningkatkan tingkat efisiensi pada penggunaan tempat tidur.

Tingkat efisiensi pelayanan rawat inap tidak cukup hanya dengan data mentah atau data dari Sensus Harian Rawat Inap (SHRI) saja, melainkan harus diolah terlebih dahulu ke dalam indikator-indikator rawat inap yaitu BOR, AvLOS, TOI dan BTO [8]. BOR (Bed Occupancy Ratio) yaitu presentase penggunaan tempat tidur pada satu satuan waktu tertentu, AvLOS (Average Length of Stay) yaitu rata-rata lama di rawat atau hari rawat seorang pasien, BTO (Bed Turn Over) yaitu frekuensi penggunaan tempat tidur pada suatu periode, dan TOI (Turn Over Interval) yaitu banyaknya hari dimana tempat tidur tidak terpakai oleh pasien. Dari keempat indikator ini hasilnya akan disajikan dalam Trend dan Grafik Barber Johnson. Trend merupakan suatu metode analisis statistik yang digunakan untuk memprediksi naik atau turunnya data digambarkan secara garis lurus dalam satu periode [9]. Grafik Barber Johnson merupakan grafik yang dikenal sebagai alat untuk menggambarkan tingkat efisiensi pada penggunaan tempat tidur.

Penelitian yang serupa sebelumnya dilakukan oleh [10] dengan judul "Analisis Trend Efisiensi Penggunaan Tempat Tidur Per Kelas Per Triwulan Berdasarkan Barber Johnson Di Rumah Sakit Umum Pusat (RSUP) Dr. Soedjadi Tirtonegoro Klaten Tahun 2018”. Hasil penelitiannya menunjukkan bahwa nilai yang sudah berada di daerah efisien adalah nilai pada indikator LOS yaitu 4 hari, TOI yaitu 1 hari, dan BOR pada Triwulan IV yaitu $76 \%$, sedangkan nilai BOR pada Triwulan I-III yaitu 71-73\% masih dibawah standar Barber Johnson yaitu idealnya 75-85\% dan nilai BTO yaitu 62 kali masih melebihi nilai 
standar menurut Barber johnson yaitu idealnya 30 pasien pertahun. Persamaan penelitian ini dengan Dyah Aprilina Retno Hastuti adalah sama-sama menggunakan standar Barber Johnson dan sama-sama menggunakan analisis trend, kemudian dalam penelitian ini variabel yang digunakan penulis dengan [10] sama yaitu Jumlah pasien keluar (D), jumlah tempat tidur tersedia (A), jumlah tempat tidur terpakai (O), jumlah hari perawatan (HP), jumlah hari dalam periode tertentu (t), BOR, LOS, TOI, BTO, serta standar efisiensi indikator BOR, LOS, TOI, dan BTO dalam grafik Barber Johnson. Perbedaan penelitian ini adalah Dyah Aprilina Retno Hastuti mengambil data periode tahun 2018 Triwulan I-IV di Rumah Sakit Umum Pusat (RSUP) dr. Soeradji Tirtonegoro Klaten, sedangkan penulis mengambil data periode tahun 2020 Triwulan I-IV di Rumah Sakit X Kota Bandung.

Penelitian yang serupa juga dilakukan oleh Erna Septiana Devi dan Asih Prasetyowati dengan judul "Trend Penggunaan Tempat Tidur Menurut Kelas di RSUD Tugurejo Semarang Tahun 2013-2017'. Hasil penelitiannya menunjukkan bahwa nilai yang sudah berada di daerah efisien adalah nilai pada indikator BOR yaitu $60-80 \%$ dan TOI yaitu 1-3 hari, sedangkan nilai AvLOS masih dibawah nilai standar yaitu 3-5 hari dan nilai BTO sebagian besar melebihi standar efisien yaitu lebih dari 50 kali. Persamaan penelitian ini dengan Erna Septiana Devi dan Asih Prasetyowati adalah sama-sama menggunakan analisis trend, kemudian dalam penilitian ini variabel yang digunakan penulis dengan Erna Septiana Devi dan Asih Prasetyowati yaitu Jumlah pasien keluar (D), jumlah tempat tidur tersedia (A), jumlah tempat tidur terpakai $(\mathrm{O})$, jumlah hari perawatan (HP), jumlah hari dalam periode tertentu (t), BOR, LOS, TOI, BTO, serta standar efisiensi indikator BOR, LOS, TOI, dan BTO dalam grafik Barber Johnson. Perbedaan penelitian ini adalah Erna Septiana Devi dan Asih Prasetyowati menggunakan standar Depkes atau standar RSUD Tugurejo Semarang sendiri dengan menggabungkan ketentuan menggunakan Barber Johnson untuk membuat grafik Barber Johnson dan mengambil data periode tahun 20132017 menurut kelas di RSUD Tugurejo Semarang, sedangkan penulis menggunakan standar Barber Johnson dan mengambil data periode tahun 2020 Triwulan I-IV di Rumah Sakit X Kota Bandung untuk membuat grafik Barber Johnson.

Berdasarkan hasil survey awal di Rumah Sakit X Kota Bandung salah satu indikator pelayanan rawat inap pada Triwulan I-IV Tahun 2020 yaitu nilai BOR (Bed Occupancy Rate) menunjukan angka tertinggi pada Triwulan I $(60,57 \%)$ dan terendah pada Triwulan II $(20,7 \%)$ yang belum mencapai tingkat efisiensi, sedangkan standar ideal menurut Barber Johnson BOR adalah 75-85\%, AvLOS adalah 3-12 hari, TOI adalah 1-3 hari, BTO adalah 30 kali (Rustiyanto, 2012). Untuk meningkatkan nilai BOR sebaiknya melakukan evaluasi pemakaian tempat tidur per ruangan atau kelas, dan mempromosikan lebih luas lagi agar adanya peningkatan dalam jumlah pasien berobat. Rumah Sakit dapat membuat Grafik Barber Johnson untuk lebih mudah melihat tingkat efisiensi BOR, AvLOS, TOI, dan BTO.

Di Rumah Sakit X Kota Bandung belum terdapat Analisis trend BOR, AvLOS, TOI, BTO, dan Grafik Barber Johnson yang berguna untuk peramalan mengenai kebutuhan tempat tidur. Berdasarkan uraian tersebut, serta melihat pentingnya analisa trend yang dapat dijadikan sebagai bahan perencanaan dan evaluasi, Peneliti tertarik untuk melakukan penelitian yang berjudul "Analisis Trend dan Grafik Barber Johnson Pada Efisiensi Tempat Tidur Di Rumah Sakit X Kota Bandung"

\section{METODE PENELITIAN}

Jenis penelitian ini adalah penelitian kualitatif dengan pendekatan deskriptif yang dilakukan untuk memberikan gambaran atau deskripsi tentang efisiensi penggunaan tempat tidur secara objektif [11]. Variabel yang digunakan dalam penelitian ini adalah jumlah hari perawatan (HP), jumlah tempat tidur terpakai (O), jumlah tempat tidur tersedia (A), jumlah pasien hidup dan mati (D), BOR, AvLOS, TOI, BTO, Grafik Barber Johnson dan Trend pada Triwulan I- IV tahun 2020. Penulis memperoleh data dari rekapitulasi laporan 3 
(RL3) tahun 2020. Penelitian ini dilaksanakan pada bulan April sampai Mei tahun 2021 di Rumah Sakit X Kota Bandung.

Analisis data dilakukan dengan analisis trend. Analisis Trend merupakan suatu metode analisis statistik yang digunakan untuk memprediksi naik atau turunnya data digambarkan secara garis lurus dalam satu periode [9]. Berikut rumus untuk menghitung nilai trend:

$\mathbf{Y}=\mathbf{a}+\mathbf{b X}$

Keterangan:

$\mathrm{Y}=$ Variabel yang diramalkan

$\mathrm{a}=$ Nilai konstanta

$\mathrm{b}=$ Kemiringan atau perubahan nilai $\mathrm{Y}$ dari waktu ke waktu

$\mathrm{X}=$ Periode waktu (tahun)

Sedangkan untuk mencari nilai konstanta (a) dan parameter (b) menggunakan rumus:

$\mathbf{a}=\frac{\sum y}{N} \quad \mathbf{b}=\frac{\sum x y}{\sum x^{2}}$

\section{HASIL DAN PEMBAHASAN}

\subsection{Hasil}

Trend BOR Di Rumah Sakit X Kota Bandung Pada Triwulan I-IV Tahun 2020

BOR atau Bed Occupancy Rate adalah presentase pemakaian tempat tidur pada satu satuan waktu tertentu. Berikut rumus untuk menghitung nilai BOR:

$$
\text { BOR }=\frac{\mathrm{O}}{\mathrm{A}} X 100 \%
$$

Keterangan :

$\mathrm{O}=$ Rata-rata tempat tidur terisi

$\mathrm{A}=$ Rata-rata tempat tidur yang siap pakai

Berdasarkan hasil penelitian di Rumah Sakit X Kota Bandung dapat diketahui nilai BOR seperti tersaji pada Tabel 1 berikut.

Tabel 1. Perhitungan BOR di Rumah Sakit X Kota Bandung pada Triwulan I-IV Tahun 2020

\begin{tabular}{ccccccc}
\hline Triwulan & HP (Hari) & T (Hari) & O (HP/t) & D & A & BOR (\%) \\
\hline I & 3473 & 91 & 38,17 & 1636 & 63 & 60,57 \\
\hline II & 1187 & 91 & 13.04 & 557 & 63 & 20,7 \\
\hline III & 2037 & 92 & 22,14 & 992 & 56 & 39,54 \\
\hline IV & 1926 & 92 & 62,81 & 976 & 56 menjadi 44 & 43,62 \\
\hline
\end{tabular}

Sumber: Data Rekapitulasi Laporan RL.3 dan Hasil Perhitungan, 2021

Berdasarkan tabel 1 dapat diketahui bahwa nilai BOR di Rumah Sakit X Kota Bandung yang tertinggi pada Triwulan I tahun 2020 yaitu 60,57\% dan pada Triwulan II tahun 2020 yaitu 20,7\% menjadi nilai terendah pada periode tahun 2020. Berdasarkan data diatas maka dapat diketahui trend BOR di Rumah Sakit X Kota Bandung pada Triwulan IIV pada Tahun 2020 sebagai berikut: 
Tabel 2. Perhitungan Trend BOR di Rumah Sakit X Kota Bandung pada Triwulan IIV Tahun 2020

\begin{tabular}{cccc}
\hline Triwulan & koding $(\mathbf{x})$ & Persamaan $\mathbf{Y}=\mathbf{4 1 , 1 0 7 5 + - 1 , 6 0 0 5 ~ X}$ & Titik Trend \\
\hline I & -3 & $\mathrm{Y}=41,1075+-1,6005(-3)$ & 45,909 \\
\hline II & -1 & $\mathrm{Y}=41,1075+-1,6005(-1)$ & 42,708 \\
\hline III & 1 & $\mathrm{Y}=41,1075+-1,6005(1)$ & 39,507 \\
\hline IV & 3 & $\mathrm{Y}=41,1075+-1,6005(3)$ & 36,306 \\
\hline
\end{tabular}

Sumber: Data Sekunder yang Diolah, 2021

Berdasarkan tabel 2 dapat diketahui bahwa trend BOR di Rumah Sakit X Kota Bandung mengalami penurunan pada setiap Triwulannya dengan nilai tertinggi pada Triwulan I tahun 2020 yaitu 45,909\% dan pada Triwulan IV yaitu 36,306\% menjadi nilai terendah pada periode tahun 2020. Gambaran efisiensi penggunaan tempat tidur Rumah Sakit dapat dilihat pada grafik berikut.

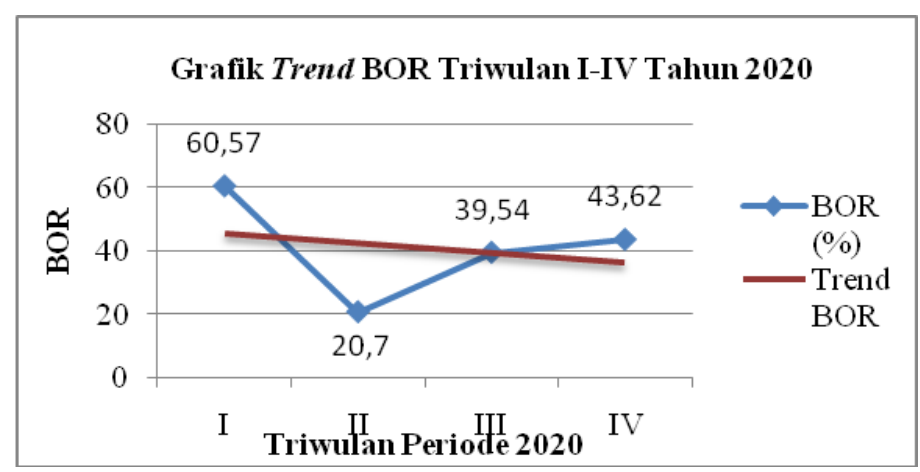

Sumber: Data Sekunder yang Diolah, 2021

Gambar 1. Trend BOR di Rumah Sakit X Kota Bandung pada Triwulan I-IV Tahun 2020

Berdasarkan gambar 1 menunjukkan bahwa trend BOR belum efisensi selama periode Tahun 2020.

Trend AvLOS Di Rumah Sakit X Kota Bandung Pada Triwulan I-IV Tahun 2020

AvLOS atau Length of Stay merupakan rata-rata jumlah hari pasien rawat inap yang tinggal di rumah sakit, tidak termasuk bayi lahir. Berikut rumus untuk menghitung nilai AvLOS :

$$
\operatorname{LOS}=\frac{\mathrm{OXt}}{\mathrm{D}}
$$

Keterangan :

$\mathrm{O}=$ rata-rata tempat tidur yang terisi

$\mathrm{D}=$ pasien keluar $(\mathrm{H}+\mathrm{M})$

$\mathrm{t}=$ Waktu (hari/bulan/tahun)

Berdasarkan hasil penelitian di Rumah Sakit X Kota Bandung dapat diketahui nilai AvLOS seperti tersaji pada tabel 3 berikut.

Tabel 3. Perhitungan AvLOS di Rumah Sakit X Kota Bandung pada Triwulan I-IV Tahun 2020

\begin{tabular}{ccccccc}
\hline Triwulan & HP (Hari) & T (Hari) & O (HP/t) & D & A & AvLOS \\
\hline I & 3473 & 91 & 38,17 & 1636 & 63 & 2,12 \\
\hline II & 1187 & 91 & 13.04 & 557 & 63 & 2,13 \\
\hline III & 2037 & 92 & 22,14 & 992 & 56 & 2,05 \\
\hline IV & 1926 & 92 & 62,81 & 976 & 56 menjadi 44 & 1,97 \\
\hline
\end{tabular}

Sumber: Data Rekapitulasi RL.3 dan Hasil Perhitungan, 2021 
Berdasarkan tabel 3 dapat diketahui bahwa nilai AvLOS di Rumah Sakit X Kota Bandung yang tertinggi pada Triwulan II tahun 2020 yaitu 2,13 hari dan pada Triwulan IV tahun 2020 yaitu 1,97 hari menjadi nilai terendah pada periode tahun 2020. Berdasarkan data diatas maka dapat diketahui trend AvLOS di Rumah Sakit X Kota Bandung pada Triwulan I-IV pada Tahun 2020 sebagai berikut:

Tabel 4. Perhitungan Trend AvLOS di Rumah Sakit X Kota Bandung pada Triwulan I-IV Tahun 2020

\begin{tabular}{cccc}
\hline Triwulan & koding $(\mathbf{x})$ & $\mathbf{Y}=\mathbf{2 , 0 6 7 5 + - \mathbf { 0 , 0 2 6 5 } \mathbf { X }}$ & Titik Trend \\
\hline I & -3 & $\mathrm{Y}=2,0675+-0,0265(-3)$ & 2,147 \\
\hline II & -1 & $\mathrm{Y}=2,0675+-0,0265(-1)$ & 2,094 \\
\hline III & 1 & $\mathrm{Y}=2,0675+-0,0265(1)$ & 2,041 \\
\hline IV & 3 & $\mathrm{Y}=2,0675+-0,0265(3)$ & 1,988 \\
\hline
\end{tabular}

Sumber: Data Sekunder yang diolah, 2021

Berdasarkan tabel 4 dapat diketahui bahwa trend AvLOS di Rumah Sakit X Kota Bandung mengalami penurunan pada setiap Triwulannya dengan nilai tertinggi pada Triwulan I tahun 2020 yaitu 2,147 hari dan pada Triwulan IV yaitu 1,988 hari menjadi nilai terendah pada periode tahun 2020. Gambaran efisiensi dapat dilihat pada grafik berikut.

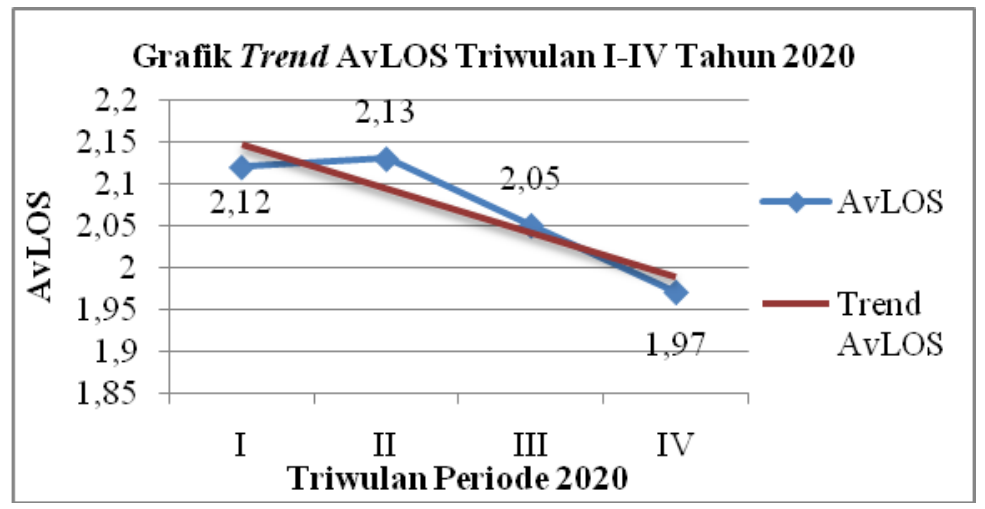

Sumber: Data Sekunder yang diolah, 2021

\section{Gambar 2. Trend AvLOS di Rumah Sakit X Kota Bandung pada Triwulan I-IV} Tahun 2020

Berdasarkan gambar 2 menunjukkan bahwa trend AvLOS mengalami penurunan selama periode Tahun 2020

\section{Trend TOI Di Rumah Sakit X Kota Bandung Pada Triwulan I-IV Tahun 2020}

TOI atau Turn Over Interval merupakan lamanya rata-rata tempat tidur kosong atau rata-rata tempat tidur tersedia pada periode tertentu yang tidak terisi antara pasien keluar atau mati dengan pasien masuk. Berikut rumus untuk menghitung nilai TOI:

$$
\text { TOI }=\frac{(A-0) X t}{\mathrm{D}}
$$

Keterangan:

$\mathrm{O}=$ Rata-rata tempat tidur yang terisi

$\mathrm{A}=$ Rata-rata tempat tidur yang siap pakai

$\mathrm{D}=$ Pasien keluar $(\mathrm{H}+\mathrm{M})$

$\mathrm{t}=$ Waktu (hari/bulan/tahun)

Berdasarkan hasil penelitian di Rumah Sakit X Kota Bandung dapat diketahui nilai TOI seperti tersaji pada tabel 5 berikut. 
Tabel 5. Perhitungan TOI di Rumah Sakit X Kota Bandung pada Triwulan I-IV Tahun 2020

\begin{tabular}{ccccccc}
\hline Triwulan & HP (Hari) & T (Hari) & O (HP/t) & D & A & TOI \\
\hline I & 3473 & 91 & 38,17 & 1636 & 63 & 1,38 \\
\hline II & 1187 & 91 & 13,04 & 557 & 63 & 8,16 \\
\hline III & 2037 & 92 & 22,14 & 992 & 56 & 3,14 \\
\hline IV & 1926 & 92 & 62,81 & 976 & 56 menjadi 44 & 2,56 \\
\hline
\end{tabular}

Sumber: Data Rekapitulasi RL.3 dan Hasil Perhitungan, 2021

Berdasarkan tabel 5 dapat diketahui bahwa nilai TOI di Rumah Sakit X Kota Bandung yang tertinggi pada Triwulan II tahun 2020 yaitu 8,16 kali dan pada Triwulan I tahun 2020 yaitu 1,38 kali menjadi nilai terendah selama periode 2020. Berdasarkan data diatas maka dapat diketahui trend TOI di Rumah Sakit X Kota Bandung pada Triwulan I-IV pada Tahun 2020 sebagai berikut:

Tabel 6. Perhitungan Trend TOI di Rumah Sakit X Kota Bandung pada Triwulan IIV Tahun 2020

\begin{tabular}{|c|c|c|c|}
\hline Triwulan & Koding (x) & $\begin{array}{c}\text { Persamaan } \\
\mathrm{Y}=\mathbf{3 , 8 1 + - 0 , 0 7 4 X} \mathrm{X}\end{array}$ & Titik Trend \\
\hline $\mathrm{I}$ & -3 & $Y=3,81+-0,074(-3)$ & 3,03 \\
\hline II & -1 & $Y=3,81+-0,074(-1)$ & 3,88 \\
\hline III & 1 & $Y=3,81+-0,074(1)$ & 3,74 \\
\hline IV & 3 & $Y=3,81+-0,074(3)$ & 3,59 \\
\hline
\end{tabular}

Sumber: Data Sekunder yang Diolah, 2021

Berdasarkan tabel 6 dapat diketahui bahwa tend TOI tidak stabil dari waku kewaktu mengalami naik dan turun dengan nilai tertinggi pada Triwulan II adalah 3,88 hari dan pada Triwulan I adalah 3,03 hari menjadi nilai terendah pada periode tahun 2020. Gambaran efisiensi dapat dilihat pada grafik berikut.

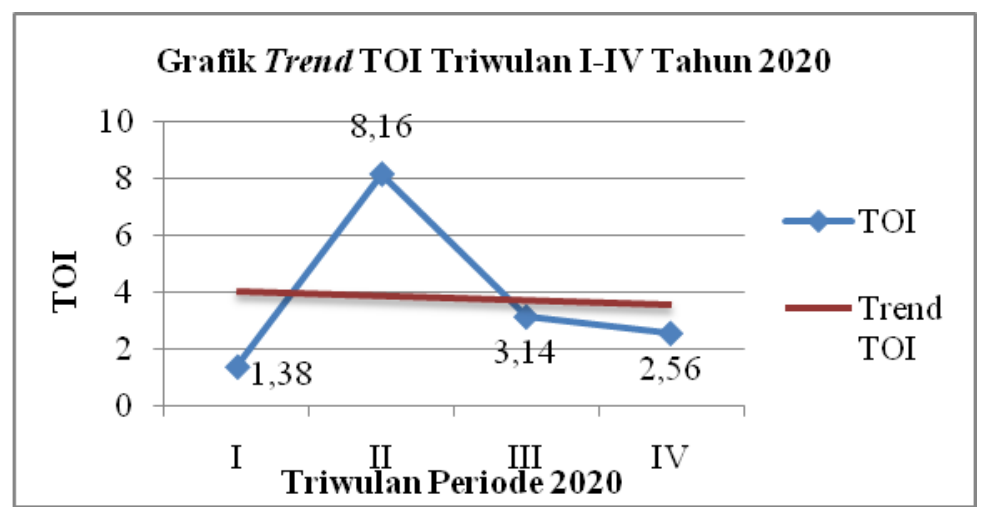

Sumber: Data Sekunder yang Diolah, 2021

\section{Gambar 3. Trend TOI di Rumah Sakit X Kota Bandung pada Triwulan I-IV Tahun} 2020

Berdasarkan gambar 3 dapat diketahui bahwa nilai trend TOI mengalami kenaikan pada Triwulan II dari 1,38 hari menjadi 8,16 hari sehingga pada Triwulan II menjadi nilai angka tertinggi, sedangkan nilai angka terendah pada Triwulan I yaitu 1,38

\section{Trend BTO Di Rumah Sakit X Kota Bandung Pada Triwulan I-IV Tahun 2020}

BTO atau Bed Trun Over merupakan berapa kali satu tempat tidur dipakai oleh pasien dalam periode tertentu. Berikut rumus untuk menghitung nilai BTO:

$$
\text { вто }=\frac{D}{A}
$$


Keterangan :

A = Rata-rata tempat tidur yang siap pakai

$\mathrm{D}=$ Pasien keluar $(\mathrm{H}+\mathrm{M})$

Berdasarkan hasil penelitian di Rumah Sakit X Kota Bandung dapat diketahui nilai BTO seperti tersaji pada Tabel 7 berikut.

Tabel 7. Pehitungan BTO di Rumah Sakit X Kota Bandung pada Triwulan I-IV Tahun 2020

\begin{tabular}{ccccccc}
\hline Triwulan & HP $($ Hari) & T (Hari) & O (HP/t) & D & A & B TO \\
\hline I & 3473 & 91 & 38,17 & 1636 & 63 & 25,97 \\
\hline II & 1187 & 91 & 13,04 & 557 & 63 & 8,84 \\
\hline III & 2037 & 92 & 22,14 & 992 & 56 & 17,71 \\
\hline IV & 1926 & 92 & 62,81 & 976 & 56 menjadi 44 & 6,78 \\
\hline
\end{tabular}

Sumber: Data Rekapitulasi Laporan RL 3 dan Hasil Perhitungan, 2021

Berdasarkan tabel 7 dapat diketahui bahwa nilai BTO di Rumah Sakit X Kota Bandung yang tertinggi pada Triwulan I Tahun 2020 adalah 25,97 kali dan pada Triwulan IV adalah 6,78 kali menjadi nilai terendah pada periode tahun 2020. Berdasarkan data diatas dapat diketahui trend BTO di Rumah Sakit X Bandung pada Triwulan I-IV Tahun 2020 sebagai berikut:

Tabel 8. Perhitungan Trend BTO di Rumah Sakit X Kota Bandung pada Triwulan IIV Tahun 2020

\begin{tabular}{|c|c|c|c|}
\hline \multirow{2}{*}{ Triwulan } & \multirow{2}{*}{ koding (x) } & Persamaan & \multirow{2}{*}{ Titik Trend } \\
\hline & & $Y=14,825+-2,435 X$ & \\
\hline $\mathrm{I}$ & -3 & $Y=14,825+-2,435(-3)$ & 22,13 \\
\hline II & -1 & $\mathrm{Y}=14,825+-2,435(-1)$ & 17,26 \\
\hline III & 1 & $Y=14,825+-2,435(1)$ & 12,39 \\
\hline IV & 3 & $Y=14,825+-2,435(3)$ & 7,52 \\
\hline
\end{tabular}

Sumber: Data Sekunder yang Diolah, 2021

Berdasarkan tabel 8 dapat diketahui bahwa trend BTO di Rumah Sakit X Kota Bandung mengalami penurunan pada periode Tahun 2020 dengan nilai tertinggi pada Triwulan I yaitu 22.13 kali dan pada Triwulan IV yaitu 7,52 kali menjadi nilai terendah pada periode tahun 2020. Gambaran efisiensi dapat dilihat pada grafik berikut:

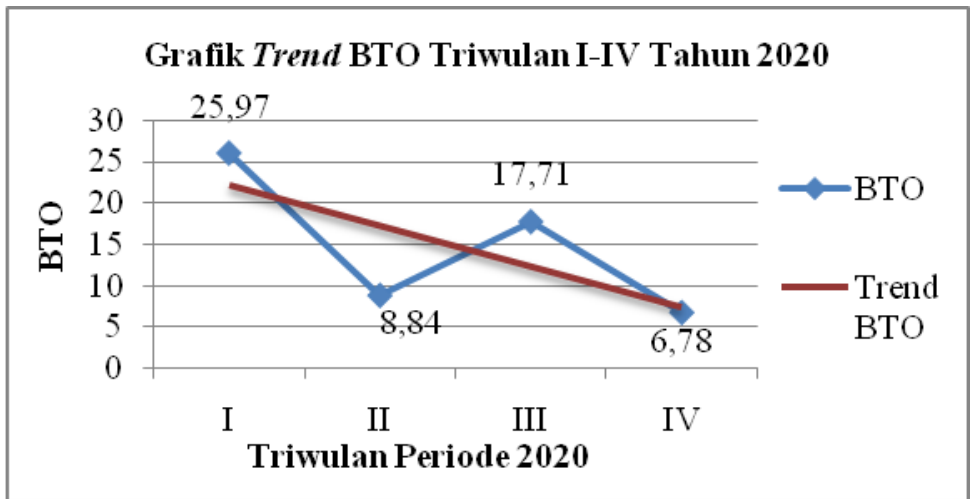

Sumber: Data Sekunder yang Diolah, 2021

Gambar 4. Trend BTO di Rumah Sakit X Kota Bandung pada Triwulan I-IV Tahun 2020 
Berdasarkan gambar 4, dapat di lihat bahwa nilai trend BTO pada Triwulan I-IV Tahun 2020 tidak stabil. Sedangkan nilai BTO tertinggi pada Triwulan I yaitu 25,97 kali dan nilai BTO terendah pada Triwulan IV yaitu 6,78 kali.

\section{Efisiensi BOR, AvLOS, TOI, BTO, Berdasarkan Grafik Barber Johnson di Rumah Sakit X Kota Bandung pada Triwulan I-IV Tahun 2020}

Indikator yang cukup tajam untuk efisiensi pada penggunaan tempat tidur dapat digambarkan dengan Grafik Barber Johnson, pada grafik ini terdapat empat parameter penilaiaan yaitu BOR, AvLOS, TOI, dan BTO. Jika titik Barber Johnson berada di dalam daerah efisien dapat dikatakan bahwa penggunaan tempat tidur di Rumah Sakit sudah Efisien [7]. Berikut gambaran penggunaan tempat tidur dengan Grafik Barber Johnson di Rumah Sakit X Kota Bandung pada Triwulan I-IV Tahun 2020.

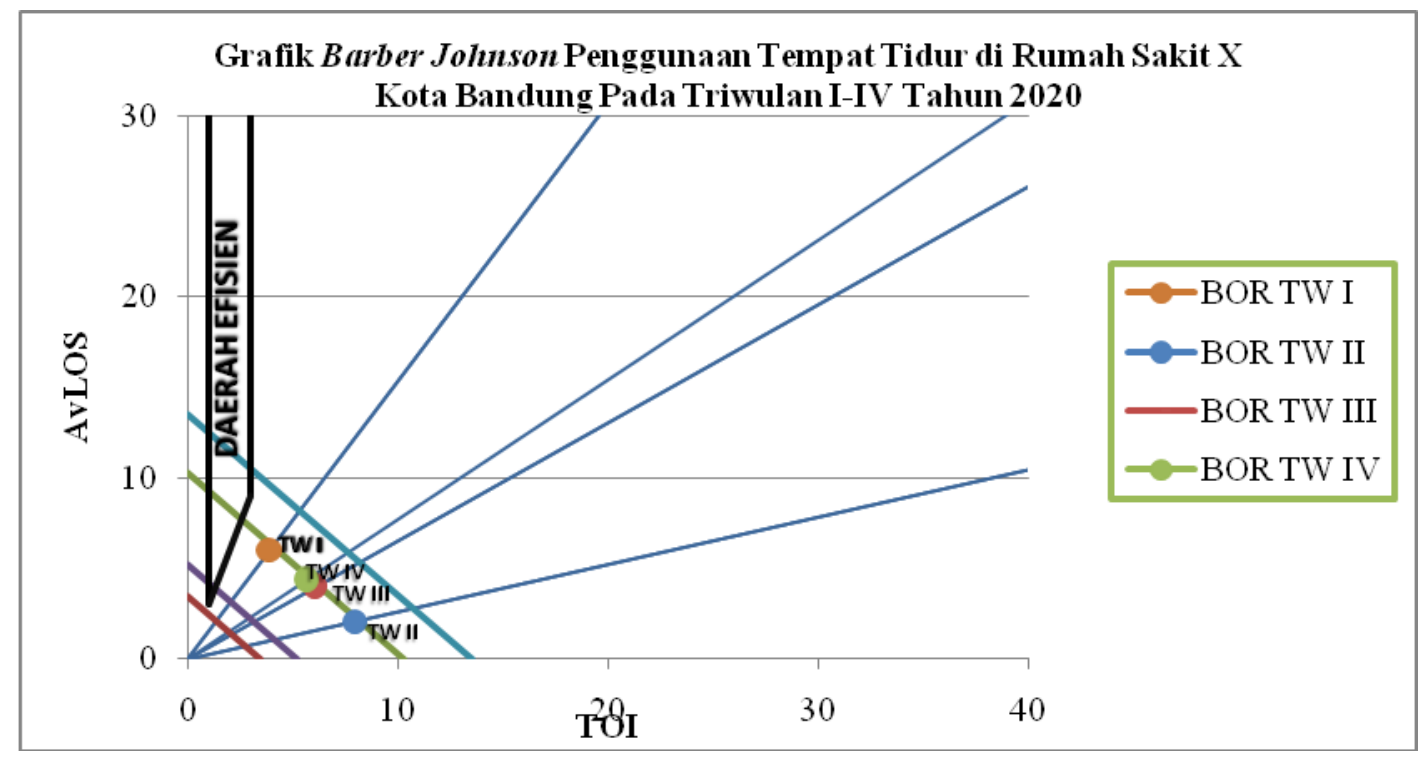

Sumber: Data Sekunder yang Diolah, 2021

Gambar 5. Efisiensi Penggunaan Tempat Tidur Berdasarkan Grafik Barber Johnson di Rumah Sakit X Kota Bandung

\subsection{Pembahasan}

Dapat di ketahui dari Grafik Barber Johnson di atas bahwa ke empat parameter yaitu BOR, AvLOS, TOI, dan BTO di Rumah Sakit X Kota Bandung masih diluar daerah efisien. Standar Grafik Barber Johnson yaitu 75\%-85\% angka trend BOR di Rumah Sakit $\mathrm{X}$ Kota Bandung pun masih belum memenuhi standar efiiensi.

Dengan nilai BOR maka dapat diketahui tinggi rendahnya tingkat penggunaan tempat tidur, di Rumah Sakit X Kota Bandung pada Triwulan I-IV Tahun 2020 masih di angka 20$60 \%$ sedangkan standar ideal pada Barber Johnson adalah 75-85\%. Menurut [12] apabila nilai BOR tinggi maka tinggi pula penggunaan tempat tidur, begitupun sebaliknya. Sejalan dengan penelitian [13] yaitu BOR yang tidak sesuai dengan standar yaitu di bawah $75 \%$, akan tetapi jika mengikuti standar Depkes (BOR ideal 60-80\%) maka angka BOR pada Triwulan I di Rumah Sakit X Kota Bandung tahun 2020 sudah mencapai nilai standar yaitu 60,57\%. Trend BOR di Rumah Sakit X Kota Bandung pada Triwulan I-IV Tahun 2020 mengalami penurunan sebesar $39,87 \%$. BOR yang rendah akan mengakibatkan tidak efisiennya manajemen keuangan pada rumah sakit, karena kurangnya pemasukan.

Trend AvLOS di Rumah Sakit X Kota Bandung pada Triwulan I-IV Tahun 2020 mengalami penurunan dalam satu periode, angka AvLOS tertinggi pada Triwulan II yaitu 2,13 hari dan angka AvLOS terendah yaitu 1,97 hari. Angka AvLOS yang menurun menandakan semakin efisiensinya pelayanan kesehatan di rumah sakit. Hasil wawancara 
dengan pihak rumah sakit AvLOS yang semakin kecil ini berkaitan dengan pelayanan JKN dengan standar AvLOS tiap kasus pelayanan pasien dan kasus pelayanan persalinan tanpa operasi. Sejalan dengan penelitian [14] maka upaya untuk mempertahankan nilai AvLOS berdasarkan standar ideal Barber Johnson perlu adanya kebijakan dari manajemen rumah sakit untuk terus meningkatkan mutu pelayanan.

Angka Trend BOR yang mengalami penurunan akan mempengaruhi angka Trend TOI (Afriania, 2017 dan Lesiangi, 2019). Trend TOI di Rumah Sakit X Kota Bandung pada Triwulan I-IV Tahun 2020 mengalami naik turun, kenaikan tertinggi pada Triwulan II dengan nilai 8,16 hari dan dengan nilai terendah pada Triwulan I dengan nilai 1,38, kembali pada batas ideal pada Triwulan III dan IV yaitu 1-3 hari berdasarkan Barber Johnson. Trend TOI menurun maka permintaan tempat tidur meningkat, karena semakin rendah angka TOI maka jarak waktu tempat tidur kosong semakin singkat untuk digunakan oleh pasien yang masuk, hal tersebut dapat menguntungkan pihak menejemen rumah sakit dari segi ekonomis.

Trend BTO di Rumah Sakit X Kota Bandung pada Triwulan I-IV tidak stabil dengan nilai tertinggi pada Triwulan I yaitu 25,97 kali dan nilai angka terendah pada Triwulan IV 6,78 kali, sehingga nilai tersebut masih belum mencapai nilai ideal karena pada Barber Johnson dalam setahun nilai standarnya itu adalah 30 pasien. Semakin rendah nilai BTO maka tempat tidur yang tidak terpakai semakin banyak, karena pasien yang memakai tempat tidur hanya sedikit, namun sebaliknya apabila nilai BTO semakin tinggi maka semakin sering tempat tidur terpakai, karena tempat tidur semakin sering digunakan oleh pasien secara bergantian. Kondisi inilah yang dapat mengancam keselamatan pasien (patient safety) sehingga dapat menimbulkan rasa ketidakpuasan pasien dan dapat meningkatkan kejadian nosokomial [12]. Diperlukannya evaluasi pemakaian tempat tidur dengan dilakukannya relokasi ke bangsal atau kelas yang tinggi permintaan tempat tidurnya.

Berdasarkan Grafik Barber Johnson diketahui bahwa penggunaan tempat tidur di Rumah Sakit X Kota Bandung pada Triwulan I-IV Tahun 2020 belum efisiensi karena keempat titik perpotongan indikator (BOR, AvLOS, TOI, dan BTO) berada diluar daerah efisiensi. Sedangkan nilai indikator yang belum efisiensi yaitu rendahnya nilai BOR, AvLOS, dan TOI. Hal tersebut karena kurang baiknya perencanaan dalam memberikan pelayanan kepada pasien atau kebijakan dibidang medis [15]. Penelitian [16] dan [17] menunjukan bahwa analisis efisiensi penggunaan tempat tidur tiap bangsal dan kelas dapat memberikan evaluasi lebih detail sehingga menajemen ruangan dapat lebih optimal.

\section{KESIMPULAN}

Berdasarkan penelitian yang dilakukan maka peneliti memperoleh kesimpulan yaitu:

1. Berdasarkan perhitungan trend dibuktikan bahwa garis trend cenderung menurun, garis capaian trend BOR terlihat masih dibawah batas minimal dan diketahui bahwa garis trend menunjukan penurunan sebesar 39,87\%.

2. Capaian pada trend AvLOS mengalami penurunan dari yang tertinggi pada Triwulan II yaitu 2,13 hari dan yang terendahl pada Triwulan IV yaitu 1,97 hari.

3. Capaian angka trend TOI menunjukkan bahwa adanya kenaikan pada Triwulan II yang sangat drastis yaitu 8,16 hari, namun angka kembali menurun pada Triwulan II dan III sehingga garis trend cenderung menurun.

4. Capaian garis kecenderungan trend BTO yang menunjukkan akan adanya penurunan setiap bulannya. Hal ini menunjukkan bahwa dengan perhitungan efisiensi dan prediksi trend menggambarkan bahwa diperlukannya menejemen relokasi tempat tidur dan peningkatan kualitas pelayanan. 
5. Dapat diprediksi indikator TOI akan semakin efisien, sedangkan indikator BOR, AvLOS, dan BTO semakin tidak efisien karena nilainya semakin menjauh dari nilai standar yang telah ditentukan.

6. Efisiensi grafik Barber Johnson di Rumah Sakit X Kota Bandung pada Triwulan I-IV Tahun 2020 berada diluar daerah efisiensi, permasalahan yang terkait dengan analisis grafik Barber Johnson yaitu laporan yang dibuat masih manual dan sering terjadinya keterlambatan dalam proses pengiriman laporan sensus harian dari beberapa unit terkait.

\section{REFERENCES}

[1] Depkes, Undang-Undang No. 36 Tahun 2009 Tentang Kesehatan. Jakarta: Depkes RI, 2009.

[2] Kemenkes, Keputusan Menteri Kesehatan No. 129/Menkes/SK/II/2008 Tentang Standar Pelayanan Minimal Rumah Sakit. Menteri Kesehatan Republik Indonesia, 2008.

[3] Hatta and R. Gemala, Pedoman Manajemen Informasi Kesehatan di Sarana Pelayanan Kesehatan. Jakarta: Universitas Indonesia, 2012.

[4] Kemenkes, Peraturan Menteri Kesehatan No. 269/Menkes/Per/III /2008 Tentang Rekam medis. Menteri Kesehatan Republik Indonesia, 2008.

[5] Depkes, Undang-Undang No 44 Tahun 2009 Tentang Rumah Sakit. Jakarta: Depkes RI, 2009.

[6] Kemenkes, Peraturan Menteri Kesehatan Republik Indonesia No 1171 Tahun 2011 tentang Sistem Informasi Rumah Sakit. Menteri Kesehatan Republik Indonesia, 2011.

[7] E. Rustiyanto, Sistem Informasi Manajemen Rumah Sakit Yang Terintegrasi. Yogyakarta: Gosyen Psdublishing, 2012.

[8] Soejadi, Efisiensi Pengelolaan Rumah Sakit. Jakarta: Katiga Bina, 1985.

[9] M. Hasan, Pokok-Pokok Statistik 1 (Statistik Deskriptif). Jakarta: Pt Bumi Aksara, 2012.

[10] Dyah Aprilia, Analisis Trend Efisiensi Penggunaan Tempat Tidur Per Kelas Per TriwulanBerdasarkan Barber Jhonson di Rumah Sakit UmumPusat (RSUP) Dr. Soedjadi Tirtonegoro Klaten Tahun 2018. Universitas Duta Bangsa, 2018.

[11] Notoadmodjo and Soekidjo, Metodologi Penelitian Kesehatan. Jakarta: Rineka Cipta, 2018.

[12] R. Sudra, Statistik Rumah Sakit dari Sensus Pasien dan Grafik Barber Johnson Hingga statistik kematian dan otopsi. Yogyakarta: Graha Ilmu, 2010.

[13] Aulia Dwijayanti, Vavi, "Prediksi Kebutuhan Tempat Tidur Pada Bangsal Yang Tidak Efisien di RSUD Ungaran Berdasarkan Standar Ideal Barber Johnson Tahun 2019 - 2023," Stikes HAKLI, 2019.

[14] Irmawati, dkk, "Efisiensi Penggunaan Tempat Tidur Berdasarkan Grafik Barber Johnson. Jurnal Rekam Medis dan Informasi Kesehatan," vol. 1, no. 2, 2018.

[15] Rustiyanto, Statistik Rumah Sakit Untuk Mengambil Keputusan. Yogyakarta: Graha Ilmu, 2010.

[16] Rinjani, Viki, and E. Triyanti, “Analisis Efisiensi Penggunaan Tempat Tidur per Ruangan Berdasarkan Indikator Depkes dan Barber Johnson di Rumah Sakit Singaparna Medika Citra Utama Kabupaten Tasikmalaya Triwulan 1 Tahun 2016," J. MIKI, vol. 4, no. 2, 2016.

[17] Devi, E. Septiani, and A. Prasetyowati, "Trend Penggunaan Tempat Tidur Menurut Kelas Di Rsud Tugurejo Semarang Tahun 2013 - 2017," Pros. Call Pap. SMIKNAS, 2019. 


\section{BIOGRAPHIES OF AUTHORS}

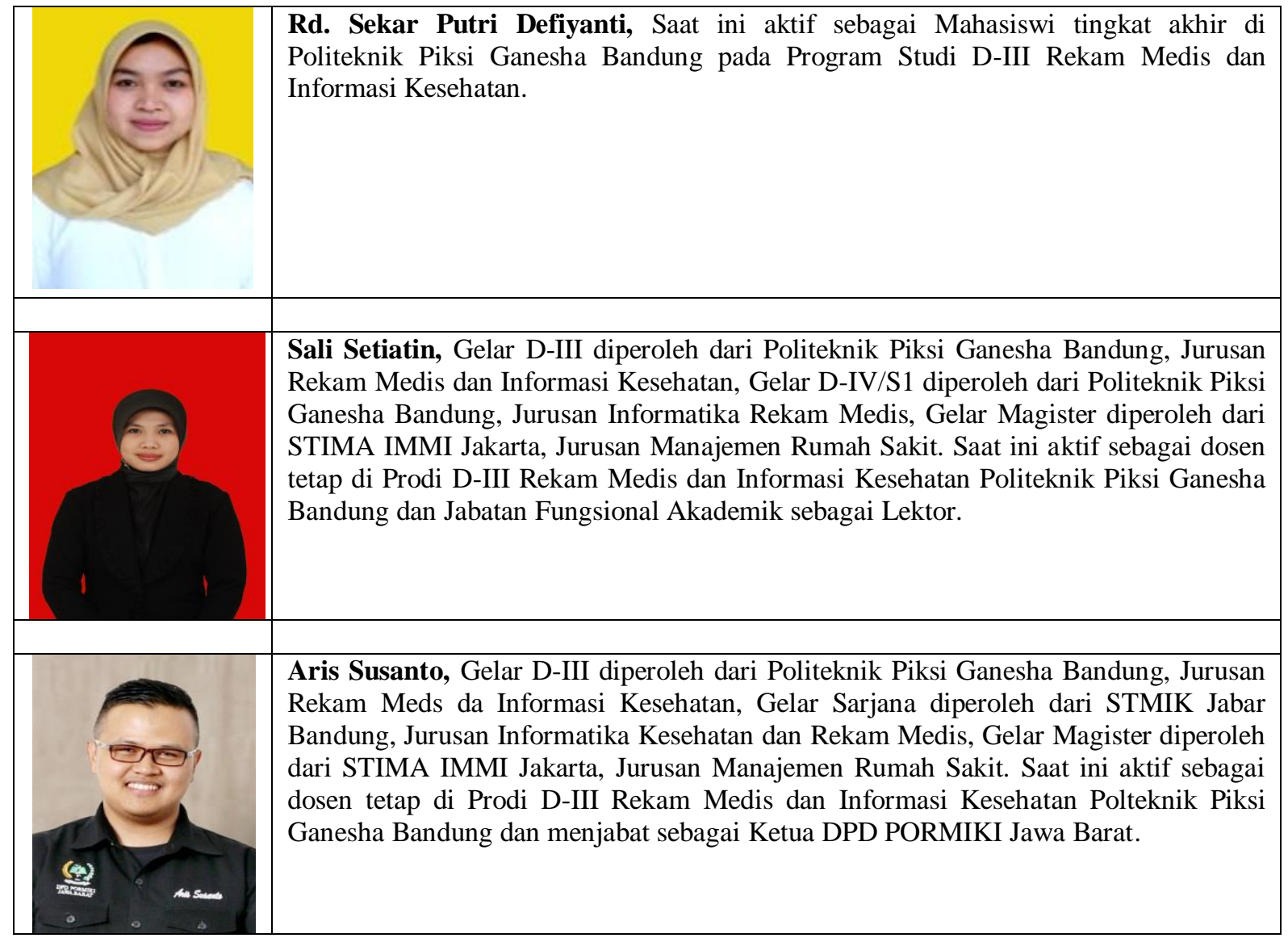

